\title{
Separation of Apolipoproteins of Human Very Low Density Lipoproteins by Chromatofocusing
}

\author{
By W. März and W. Groß \\ Gustav Embden Zentrum der Biologischen Chemie der J. W. Goethe-Universität, Frankfurt/Main
}

(Received September 7, 1982/January 19, 1983)

Summary: Chromatofocusing represents a new chromatographic procedure for the separation of proteins according to their isoelectric points. We describe the application of this method for the fractionation of the urea-soluble apolipoproteins of very low density lipoproteins. They were separated into five peaks, four of which were homogeneous as judged by polyacrylamide gel electrophoresis in the presence of $7 \mathrm{~mol} / \mathrm{l}$ urea.

\section{Trennung von Apolipoproteinen der menschlichen VLDL durch Chromatofokussierung}

Zusammenfassung: Die Chromatofokussierung stellt ein neues chromatographisches Verfahren zur Trennung von Proteinen nach ihrem isoelektrischen Punkt dar. Wir beschreiben die Anwendung dieser Methode für die Fraktionierung der harnstofflöslichen Apolipoproteine der VLDL. Sie wurden in fünf peaks aufgetrennt, von denen bei Untersuchung mittels Polyacrylamidgel-Elektrophorese in Anwesenheit von Harnstoff vier homogen waren.

\section{Introduction}

Characterization of the apolipoproteins of human very low density lipoproteins (VLDL) requires suitable methods for their separation and purification. So far, a large variety of chromatographic methods such as gel filtration, ion-exchange chromatography, affinity chromatography and isoelectric focusing in dextran-stabilized beds, either alone or in combination have been used $(1-5)$. This report describes the application of chromatofocusing for the separation of the apolipoproteins of VLDL.

\section{Materials and Methods}

To obtain sufficient material, sera from normal and hyperlipidaemic subjects were pooled. No preselection was made with regard to the serum lipid levels, except that sera revealing the presence of chylomicrons after standing overnight at $+4^{\circ} \mathrm{C}$ were excluded.

\section{Isolation of $V L D L$}

Very low density lipoproteins were isolated by ultracentrifugation $(\mathrm{d}<1.0063 \mathrm{~kg} / \mathrm{l}$ ) using a fixed angle rotor (type $50.2 \mathrm{Ti}$ ) in a Beckman ultracentrifuge ( $L$ 2-50 B or L 5-50 B). In polycarbo- nate tubes, $20 \mathrm{ml}$ of pooled serum were overlayered with $6 \mathrm{ml}$ of a solution containing $0.195 \mathrm{~mol} / \mathrm{l} \mathrm{NaCl}$ and $0.27 \mathrm{mmol} / 1 \mathrm{Na} 2$ EDTA and spun for at least 18 hours at $40000 \mathrm{~min}^{-1}\left(1.565 \cdot 10^{8}\right.$ $g \cdot \min )$. Floated VLDL were removed using a syringe (approximately $7 \mathrm{ml})$ and the protein content $(0.8-1.0 \mathrm{~g} / 1)$ was estimated by the method of Markwell et al. (6). Since no albumin was detected by radial immunodiffusion using LC-Partigen immunodiffusion plates (Behringwerke, Marburg) $(25 \mathrm{mg} / \mathrm{l}$ can easily be detected by this assay), the VLDL preparation was not recentrifuged.

\section{Delipidation of $V L D L$}

Delipidation was performed according to a method of Augustin \& Haberbosch (7). The VLDL were dialysed against distilled water containing $0.27 \mathrm{mmol} / 1 \mathrm{Na}_{2} \mathrm{EDTA}$ and subsequently lyophilized. Aliquots of $0.5 \mathrm{~g}$ of lyophilized VLDL were extracted with $100 \mathrm{ml}$ n-heptane under constant stirring at $-15^{\circ} \mathrm{C}$ for 4 hours. The proteins were sedimented by centrifugation at $3000 \mathrm{~min}^{-1}$ at $-15^{\circ} \mathrm{C}$ for 15 minutes, and the lipid-containing organic phase was removed. The pellet was extracted twice with ethanol: ether $(3+1$ by vol.), once for 4 hours, followed by overnight. Finally, an extraction with diethylether for 4 hours was performed and the pelleted proteins were dried under a gentle stream of nitrogen.

The dried apolipoproteins were solubilized in $25 \mathrm{mmol} / \mathrm{imid}$ azole- $\mathrm{HCl}$-buffer, $\mathrm{pH} \mathrm{7.4}$, containing $8 \mathrm{mmol} / \mathrm{h}$ urea (Merck, suprapur) and $10 \mathrm{mmol} / \mathrm{h}$ dithiothreitol under constant stirring at $-4^{\circ} \mathrm{C}$ overnight. The insoluble apolipoprotein $\mathrm{B}$ was sedimented by centrifugation at $4000 \mathrm{~min}^{-1}$ for 30 minutes, and the supernatant containing the urea-soluble proteins was immediately applied to the pre-equilibrated chromatofocusing column. 


\section{Chromatofocusing}

A column K 16/70 (Pharmacia) was packed with Pharmacia polybuffer exchanger (PBE 94) to a height of $60 \mathrm{~cm}$ resulting in a final bed volume of $120 \mathrm{ml}$ with a flow rate corresponding to $400 \mathrm{~cm} / \mathrm{h}$. The column was equilibrated with start buffer $(25 \mathrm{mmol} / 1 \mathrm{imid}-$ azole- $\mathrm{HCl}$-buffer, $\mathrm{pH} \mathrm{7.4)} \mathrm{containing} 8 \mathrm{~mol} / \mathrm{l}$ urea and $10 \mathrm{mmol} / \mathrm{h}$ dithiothreitol. Fifteen bed volumes of buffer were needed for equilibration. All buffer solutions were thoroughly degassed to avoid fluctuations in the $\mathrm{pH}$-gradient due to bicarbonate ions. $20 \mathrm{ml}$ of material containing approximately $100 \mathrm{mg}$ apolipoproteins were applied to the column. Elution was performed with polybuffer 74 (Pharmacia) containing $8 \mathrm{~mol} / /$ urea at a constant flow rate $(25 \mathrm{ml} / \mathrm{h})$ and constant temperature $\left(10^{\circ} \mathrm{C}\right)$. Before use, the polybuffer was diluted $1: 8$ with distilled water and the $\mathrm{pH}$ adjusted to 4.0 with $0.5 \mathrm{~mol} / \mathrm{HCl}$. The gradient volume for the pH-interval of 3 units was approximately 1 liter. The protein content of the effluent was monitored with a LKB uvicord at a wavelength of $280 \mathrm{~nm}$. Absorbance (range: 0-0.1) and transmission (\%) were registered simultaneously. $4 \mathrm{ml}$ fractions were collected with a LKB fraction collector. The shape of the $\mathrm{pH}$-gradient was determined by measuring the $\mathrm{pH}$ at room temperature in every fifth tube of the column effluent. Fractions containing maximum apolipoprotein concentrations were measured separately in order to determine their respective apparent isoelectric point in the system at $10^{\circ} \mathrm{C}$. The column was regenerated after each run by eluting bound protein with $3-5$ bed volumes of $1 \mathrm{~mol} / 1 \mathrm{NaCl}$ solution. A further wash with $0.1 \mathrm{~mol} / 1 \mathrm{HCl}$ did not dissolve any additional material from the gel and was therefore omitted in later experiments.

\section{Separation of polybuffer from apolipoproteins}

The peak fractions were pooled as indicated by the hatched regions in figure 1 and dialysed against a $90 \%$ saturated solution of ammonium sulphate. The precipitated proteins were separated from the polybuffer-containing solution by centrifugation (30 minutes at $15000 \mathrm{~min}^{-1}$ ), then resolubilized in a small volume of Tris- $\mathrm{HCl}$-buffer, $\mathrm{pH} \mathrm{8.6,} \mathrm{containing} 6 \mathrm{~mol} / \mathrm{/rea}$. The precipitation seems to be quantitative as judged by protein determinations in the polybuffer-containing supernatants.

\section{Polyacrylaminde gel elèctrophoresis}

Polyacrylamide gel electrophoresis of apolipoproteins was performed as described by Kane (8), except that the delipidation step with tetramethylurea and the application of sucrose were omitted. We used a SHANDON disc electrophoresis chamber with a LKB power supply unit.

\section{Determination of protein}

Protein in the native VLDL preparation was measured according to Markwell et al. (6). The protein content of the urea-soluble fraction of the VLDL-apolipoproteins and of the separated apolipoproteins after ammonium sulphate precipitation was estimated according to Bensadoun \& Weinstein (9), who reported a modifi= cation of the Lowry procedure which avoids interferences in the assay due to dithiothreitol or possible residues of polybuffer. Purified human albumin served as a standard for both determinations.

\section{Results and Discussion}

Figure 1 shows the elution pattern of a typical chromatofocusing experiment. Recovery of protein in the course of the total procedure, including chromatography, dialysis against ammonium sulphate, centrifugation and resolubilization of the apolipoproteins was determined: $65 \%$ of the starting material were found in the major peak fractions ( $\mathrm{I}-\mathrm{V}$ in fig. 1 ). Additionally, small amounts of protein that were not quantified in our experiments could be eluted by washing the column with a $1 \mathrm{~mol} / 1 \mathrm{NaCl}$ solution. Thus, the recovery data correspond to those obtained by ion exchange chromatography (2), but they do not reach the values of preparative flat-bed isoelectric focusing (recovery of $80=90 \%,(5)$ ).

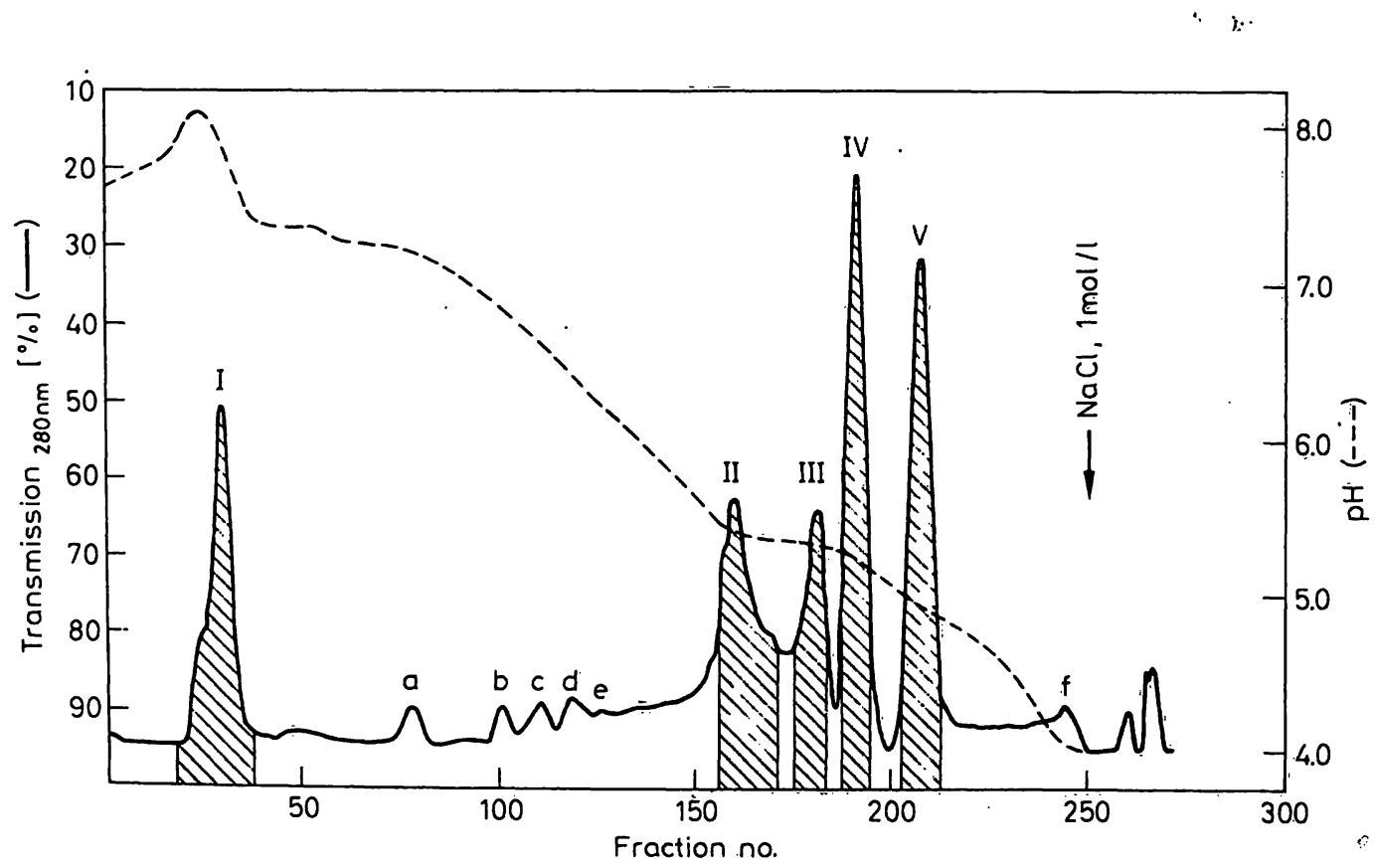

Fig. 1. Elution profile of a chromatofocusing run showing the separation of the urea-soluble apolipoproteins of human VLDL. Major peaks are designated I-V; a-f represent minor protein peaks. The apparent isoelectric points of the separated apolipoproteins were determined by $\mathrm{pH}$-measurements in fraction Nos. 160, 182,191 and 208 . Hatched areas mark the fractions that were pooled for analysis by polyacrylamide gel electrophoresis. The arrow indicates the end of the gradient at pH 4.0 and the application of $1 \mathrm{~mol} / \mathrm{N} \mathrm{NaCl}$ solution for washing. 
The major urea-soluble apolipoproteins of VLDL were separated into five peaks ( $\mathrm{I}-\mathrm{V}$ in fig. 1). The pH-gradient produced in the separating system is linear except in the range where peak II occurs.

Peak I contains material that is not bound to the polybuffer exchanger under the conditions described. In the order of their appearance in the pHgradient the $\mathrm{pH}$ of peak fractions with maximum protein concentrations were 5.47, 5.39, 5.28 and 4.98 for the peaks II, III, IV and V, respectively. Characterization of the fractions by polyacrylamide gel electrophoresis revealed the following results (fig. 2): Peak I gives a single band with the typical relative mobility of apolipoprotein C-I; peak II contains apolipoprotein E; peak III resolves into apolipoprotein C-II and a small amount of apolipoprotein $\mathrm{E}$; peak IV and $\mathrm{V}$ contain the apolipoproteins $\mathrm{C}-\mathrm{III}_{1}$ and $\mathrm{C}-\mathrm{III}_{2}$, respectively. Apolipoprotein $\mathrm{C}-\mathrm{III}_{0}$ could not be detected, presumably because its relative mobility is similar to that of apolipoprotein C-II (10). The contamination of apolipoprotein C-II by apolipoprotein E (peak III of fig. 1; site 4 in fig. 2) might be due to the slight decrease of the slope of the pH-gradient already mentioned above.

The minor fractions ( $a-f$ in fig. 1 ) have not been characterized. Comparison of the apparent isoelectric points of the apolipoproteins (derived from their elution position from the chromatofocusing column) with those reported in the literature $((5,10,11,12)$ based on analytical or preparative isoelectric focusing) shows differences between the two systems (tab. 1): the isoforms of apolipoprotein $\mathrm{C}$ elute at a higher $\mathrm{pH}$ than the $\mathrm{pI}$-values reported in the literature; whereas, at least, some isoforms of apolipopro- tein $\mathrm{E}$ appear in the effluent at a pH lower than their isoelectric points. These deviations might be due to some displacement effects occurring during chromatofocusing. Displacement of bound protein by poly-

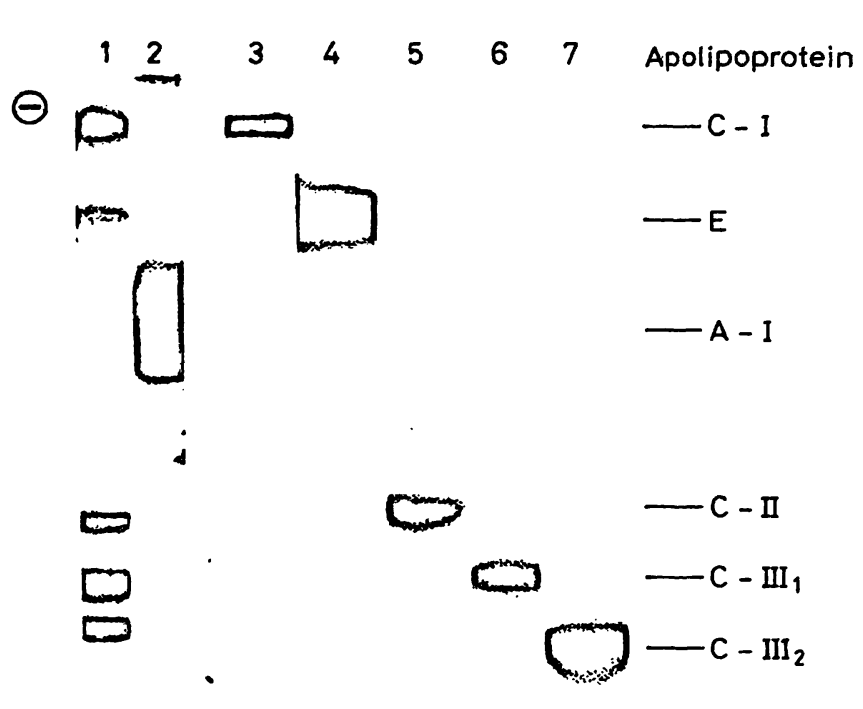

$\oplus$

$\begin{array}{lllllll}200 & 300 & 100 & 300 & 100 & 100 & 100\end{array}$ Protein $[\mu \mathrm{g} / \mathrm{gel}]$

Fig. 2. Alkaline polyacrylamide gel electrophoresis in the presence of $7 \mathrm{~mol} / \mathrm{l}$ urea.

Site 1, urea-soluble apolipoproteins of VLDL.

Site 2, purified apolipoprotein A-I for comparison.

Site 3, peak I from fig. 1.

Site 4, peak II from fig. 1.

Site 5, peak III from fig. 1 .

Site 6, peak IV from fig. 1.

Site 7 , peak $V$ from fig. 1 .

The amount of protein applied to each gel is given below the photograph.

Tab. 1. The apparent isoelectric points of apolipoproteins - comparison between published data and the behaviour of apolipoproteins in chromatofocusing

1 reported by Marcel et al. (5) using preparative isoelectric focusing with $7 \mathrm{~mol} / \mathrm{l}$ urea at $6^{\circ} \mathrm{C}$ (temperature of the $\mathrm{pH}$ measurements not given)

2 reported by Albers \& Scanu (11) using column isoelectric focusing in a sucrose density gradient with $6 \mathrm{~mol} / 1$ urea at $15^{\circ} \mathrm{C}$ (pH measurements at $25^{\circ} \mathrm{C}$ with $3 \mathrm{~mol} / \mathrm{l}$ urea)

3 reported by Catapano et al. (10) using analytical isoelectric focusing with $8 \mathrm{~mol} / 1$ urea at $4^{\circ} \mathrm{C}$ ( $\mathrm{pH}$ measurcments under the same experimental conditions)

4 reported by Warnick et al. (12) using analytical isoelectric focusing with $8 \mathrm{~mol} / 1$ urea at $2^{\circ} \mathrm{C}$ ( $\mathrm{pH}$ measurements at $4^{\circ} \mathrm{C}$ )

\begin{tabular}{|c|c|c|c|c|c|}
\hline \multirow{2}{*}{$\begin{array}{l}\text { Apolipoprotein } \\
\text { designation }\end{array}$} & \multicolumn{4}{|c|}{ Isoelectric points reported in the literature } & \multirow{2}{*}{$\begin{array}{l}\text { Apparent isoelectric points } \\
\text { (chromatofocusing, } \\
8 \mathrm{~mol} / \mathrm{l} \text { urea, } 10^{\circ} \mathrm{C} \text { ) }\end{array}$} \\
\hline & 1 & 2 & 3 & 4 & \\
\hline C-II & 5.01 & 4.79 & 4.79 & n.d. & 5.39 \\
\hline C-IIII) & 5.09 & 4.93 & 4.93 & n. d. & n. d. \\
\hline C-IIII & 4.91 & 4.70 & 4.72 & n. d. & 5.28 \\
\hline $\mathrm{C}-\mathrm{III}_{2}$ & 4.80 & 4.53 & 4.54 & n.d. & 4.98 \\
\hline$E$ isoforms & $5.7-6.2$ & n. d. & n. d. & $5.6-6.1$ & around 5.47 \\
\hline
\end{tabular}


buffer molecules, especially in the latter portion of the gradient where the polybuffer concentration increases, may cause protein to elute at a $\mathrm{pH}$ above its isoelectric point, as observed in our experiments for apolipoproteins $\mathrm{C}$-II, $\mathrm{C}-\mathrm{III}_{1}$ and $\mathrm{C}-\mathrm{III}_{2}$. On the other hand, the "late" elution of apolipoprotein $\mathrm{E}$ from the column may be due to the Donnan-potential between the positive charged gel matrix and the effluent as well as the diminished solubility of apolipoprotein $\mathrm{E}$ at its isoelectric point (13). However, as follows from table 1 , the order of elution of the ureasoluble apolipoproteins of VLDL from the chromatofocusing column corresponds well with their isoelectric points.

\section{References}

1. Brown, W. V., Levy, R. I. \& Frederickson, D. S. (1969) J. Biol. Chem. 244, 5687-5694.

2. Herbert, P. N., Shulman, R. S., Levy, R. I. \& Fredrickson, D. S. (1973) J. Biol. Chem. 248, 4941-4946.

3. Shore, V. G. \& Shore, B. (1973) Biochemistry 12, 502-507.

4. Shelburne, F. A. \& Quarfordt, S. H. (1977) J. Clin. Invest. 60, 944-950.

5. Marcel, Y. L., Bergseth, M. \& Nestruck, A. C. (1979) Biochim. Biophys. Acta 573, 175-183.

6. Markwell, M. A., Haas, S. M., Bieber, L. L. \& Tolbert, N. E. (1978) Anal. Biochem. 87, 206-210.

7. Augustin, J. \& Haberbosch, W. pers. communication.
The method described is suitable for the isolation of apolipoproteins $\mathrm{C}-\mathrm{I}, \mathrm{C}-\mathrm{III}_{1}, \mathrm{C}-\mathrm{III}_{2}$ and $\mathrm{E}$ from human VLDL in electrophoretically homogeneous form. In comparison with the efficiency of preparative isoelectric focusing (5) further work has to be done to improve the resolution, in rorder to obtain pure apolipoprotein $\mathrm{C}$-II and $\mathrm{C}$-III $\mathrm{II}_{0}$.

\section{Acknowledgements}

We wish to thank the Riese-Stiftung for financial suppoitt and Ms. H. Blümler and Ms. Ch. Heidemann for skilful technical as= sistançe.

8. Kane, J. P. (1973) Anal. Biochem. 53, 350-364.

9. Bensadoun, A. \& Weinstein, D. (1976) Anal. Biochem. 70, 241-250.

10. Catapano, A. L., Jacksoñ, R. L., Gilliam, E.B. Gotto jr., A. M. \& Smith, L. C. (1978) J. Lipid Res. 19, 1047-1052.

11. Albers, J. J. \& Scanu, A. M. (1971) Biochim. Biophys. Acta 236, 29-37.

12. Warnick, G. R., Mayfield, C., Albers, J. J. \& Hazzard, W. R. (1979) Clin. Chem. 25, 279-284.

13. Booklet by Pharmacia Fine Chemicals AB, $S-7.5104$, Uppsala 1, Sweden: Chromatofocusing with Polybuffer ${ }^{\mathrm{TM}}$ $\mathrm{PBE}^{\mathrm{TM}}$.
Prof. Dr. W. Groß

Gustav Embden-Zentrum

d. Biol. Chemie d. J. W. Goethe-Univ.

Theodor Stern-Kai 7

D-6000 Frankfurt/Mằin 70 